Geosci. Model Dev. Discuss., doi:10.5194/gmd-2016-273, 2016

Manuscript under review for journal Geosci. Model Dev.

Published: 23 November 2016

(c) Author(s) 2016. CC-BY 3.0 License.

\title{
The FuGas 2.1 framework for atmosphere-ocean coupling in geoscientific models: improving estimates of the solubilities and fluxes of greenhouse gases and aerosols
}

5 Vasco M. N. C. S. Vieira ${ }^{1}$, Pavel Jurus ${ }^{2,5}$, Emanuela Clementi ${ }^{3}$, Heidi Pettersson ${ }^{4}$ and Marcos $^{2}$ Mateus ${ }^{1}$.

${ }^{1}$ MARETEC, Instituto Superior Técnico, Universidade de Lisboa, Av Rovisco Pais, 1049-001 Lisboa, Portugal. ${ }^{2}$ DataCastor, U Svobodarny 1063/6,190 00 Praha 9, Prague, Czech Republic.

${ }^{3}$ Istituto Nazionale di Geofisica e Vulcanologia, INGV, Bologna, Italy.

${ }^{4}$ Finnish Meteorological Institute, P.O. Box 503, FI-00101 Helsinki, Finland.

${ }^{5}$ Institute of Computer Science, Czech Academy of Sciences, Prague, Czech Republic.

Correspondence to: Vasco M. N. C. S. Vieira vasco.vieira@tecnico.ulisboa.pt

ABSTRACT

Accurate estimates of the atmosphere-ocean balances and fluxes of greenhouse gases and aerosols are fundamental for geoscientific models dealing with climate change. A significant part of these fluxes occur at the coastal ocean which, although much smaller than the open ocean, is also much more heterogenic. The scientific community is becoming increasingly aware of the necessity to model the Earth at finer spatial and temporal resolutions, which also requires better descriptions of the chemical, physical and biological processes involved. The standard formulations for the gas transfer velocities and solubilities are 24 and 36 years old, respectively, and recently, new alternatives have emerged. We developed a framework congregating the geophysical processes involved which are customizable with alternative formulations with different degrees of complexity and/or different theoretical backgrounds. We propose this framework as basis for novel couplers of atmospheric and oceanographic model components. We tested it with fine resolution data from the European coastal ocean. Although the benchmark and alternative solubility formulations agreed well, their minor divergences yielded differences of many tons of greenhouse gases dissolved at the ocean surface. The transfer velocities largely mismatched their estimates, a consequence of the benchmark formulation not considering factors that were proved determinant at the coastal ocean. Climate Change research requires more comprehensive simulations of atmosphere-ocean interactions but the formulations able to do it require further calibration and validation.

Keywords: solubility, transfer velocity, Henry constant. 
Geosci. Model Dev. Discuss., doi:10.5194/gmd-2016-273, 2016

Manuscript under review for journal Geosci. Model Dev.

Published: 23 November 2016

(c) Author(s) 2016. CC-BY 3.0 License.

\section{Introduction}

Earth-System as well as Regional models are ensembles of inter-connected components, namely the land, ocean,

atmosphere and cryosphere. The exchange of information between each pair requires specific couplers that are also responsible for the estimation of geophysical processes specific to their physical interfaces. In this work we focus on the coupling between the atmospheric and the oceanographic components, and the estimation of the air-water fluxes of greenhouse gases and aerosols. The Code and Data Availability section has the link to the software, data and videos.

Because the oceans can act as sinks or sources of greenhouse gases and aerosols to the atmosphere, the dynamics of their gas exchanges are fundamental for Earth's climate. The open ocean is generally believed to uptake $\mathrm{CO}_{2}$ from the atmosphere, despite the observed seasonal, inter-annual and regional variability. In the pole regions the solubility pump retrieves large amounts of greenhouse gases from the atmosphere and transports them to the deep ocean. On the other hand, the balances and fluxes of $\mathrm{CO}_{2}, \mathrm{CH}_{4}, \mathrm{~N}_{2} \mathrm{O}$ and DMS at the coastal oceans' surface are very heterogenic due to factors like upwelling, plankton productivity and continental loads. Earth-System Models (ESM) and marine biogeochemistry usually simulate the biosphere at decadal and centennial time-scales with daily intervals and spatial resolutions of hundreds to one thousand kilometres (see ESM applications by IPCC, MPI or CMCC). Constrained by calculus demands, they estimate the atmosphere-ocean gas fluxes from simpler formulations that disregard the complexity of processes more recently unveiled at the coastal ocean. The generalization by Wanninkhof (1992), relying on wind speed $\left(\mathrm{u}_{10}\right)$ as the sole driver of transfer velocity, is the standard in current ESM at coarse resolutions. Alternatively, the regional oceanographic numerical lab MOHID allows the user to choose between the airwater gas exchange formulations by Carini et al. (1996) and Raymond and Cole (2001), only accounting for $\mathrm{u}_{10}$, or by Borges et al. (2004), also accounting for current drag with the bottom. These are empirical formulations best fitting low wind data collected from estuaries. There are many other simpler formulations estimating the air-water gas exchange considering a few factors that were determinant for that specific set of environmental conditions and optimizing the adjustment to their specific data. But modelling the coastal oceans with fine resolution requires an algorithm that, whatever the local conditions, is always able to forecast with improved accuracy due to its enhanced representation of the multitude of processes potentially present. Developing such algorithm demands for a framework able to be updated with the best formulation for each of the mediator processes involved.

The FuGas 2.1 is an upgrade of the framework by Vieira et al. (2013) congregating several of the geophysical processes involved in the air-water gas exchanges, and where each process can be simulated by one formulation chosen from an extensive list. It includes 50 alternative formulations to account for such factors as solubility, wind or current mediated turbulence, atmospheric stability, sea-surface roughness, breaking waves, air and water viscosities, temperature and salinity. We use the FuGas 2.1 to compare between the estimations of the solubilities and fluxes of greenhouse gases using the ESM standards and recent alternative formulations. First, we tested with field data from the

70 Baltic Sea. Then, we coupled the Weather Research and Forecasting (WRF) atmospheric model to the WaveWatch III (WW3) - NEMO oceanographic model using simulated data from the European coastal ocean. The calculus was vectorized and parallelized for improved computational speed.

\section{Methods}

75 Air-water gas fluxes result from the interaction of two factors: (i) the unbalance between the gas concentrations in the air and in the water sets the strength and direction of the flux, and (ii) the resistance the medium does for being crossed 
Geosci. Model Dev. Discuss., doi:10.5194/gmd-2016-273, 2016

Manuscript under review for journal Geosci. Model Dev.

Published: 23 November 2016

(c) Author(s) 2016. CC-BY 3.0 License.

by the flow. The traditional formulation estimates the flux from $\mathrm{F}=\mathrm{k}_{\mathrm{w}} \cdot \mathrm{k}_{\mathrm{H}} \mathrm{cp} \cdot \Delta \mathrm{p}_{\mathrm{gas}}$, in units of $\mathrm{mol} \cdot \mathrm{m}^{-2} \cdot \mathrm{s}^{-1}$. The $\Delta \mathrm{p}_{\text {gas }}$ is the difference between air and water gas partial pressures (atm). The $k_{H} c p$ is the Henry's constant for the gas solubility in its $\mathrm{C}_{\mathrm{w}} / \mathrm{p}_{\mathrm{a}}$ form $\left(\mathrm{mol} \cdot \mathrm{m}^{-3} \cdot \mathrm{atm}^{-1}\right)$, where $\mathrm{p}_{\mathrm{a}}$ is its air partial pressure $(\mathrm{atm})$ and $\mathrm{C}_{\mathrm{w}}$ its concentration in the water $\left(\mathrm{mol} \cdot \mathrm{m}^{-3}\right)$.

The $\mathrm{k}_{\mathrm{w}}$ is the transfer velocity of gases across the sub-millimetrically thick water surface layer in $\mathrm{m} \cdot \mathrm{s}^{-1}$ although usually plotted in $\mathrm{cm} \cdot \mathrm{h}^{-1}$. The alternative double layer model (Liss and Slater, 1974) estimates the flux taking into consideration both the water-side and air-side sub-millimetrically thick surface layers and thus, $F=K_{w}\left(C_{a} / k_{H}-C_{w}\right)=K_{a}\left(C_{a}-C_{w} \cdot k_{H}\right)$. The $\mathrm{C}_{\mathrm{a}}$ and $\mathrm{C}_{\mathrm{w}}$ are the concentrations of the gas in air and water given in $\mathrm{mol} \cdot \mathrm{m}^{-3}$ and the $\mathrm{k}_{\mathrm{H}}$ is Henry's constant in its equivalent dimensionless quantity $\left(\mathrm{C}_{\mathrm{a}} / \mathrm{C}_{\mathrm{w}}\right)$. The transfer velocity is averaged over both layers from $\mathrm{K}_{\mathrm{w}}=\left(1 / \mathrm{k}_{\mathrm{w}}+1 /\left(\mathrm{k}_{\mathrm{H}} \cdot \mathrm{k}_{\mathrm{a}}\right)\right)^{\text {- }}$

${ }^{1}$ or its equivalent $\mathrm{K}_{\mathrm{a}}=\left(\mathrm{k}_{\mathrm{H}} / \mathrm{k}_{\mathrm{w}}+1 / \mathrm{k}_{\mathrm{a}}\right)^{-1}$.

\section{$2.1 \quad$ Solubility}

Sarmiento and Gruber (2013) compiled the algorithm for the $\mathrm{k}_{\mathrm{H}} \mathrm{cp}$ dependence on temperature and salinity provided by Weiss (1974) and Weiss and Price (1980). We converted it to its corresponding dimensionless $\mathrm{k}_{\mathrm{H}}$ preserving the constants required to estimate Bunsen's solubility coefficient $\beta$. This formulation accounted for fugacity (f) of non-ideal gases (Eq. 1) and corrected the gas partial pressure for moisture effects from the expression $\mathrm{p}_{\text {moist }}=\left(1-\mathrm{p}_{\mathrm{H} 2 \mathrm{O}} / \mathrm{P}\right) \mathrm{p}_{\mathrm{dry}}$ considering water vapour saturation over the sea-surface (Eq. 2). $P$ is air pressure (atm), $T_{w}$ is water temperature (K), $S$ is salinity (\%), $\mathrm{p}$ is the gas partial pressure (atm), $\mathrm{R}$ is the ideal gas law constant $\left(\mathrm{Pa} \cdot \mathrm{m}^{3} \cdot \mathrm{mol}^{-1} \cdot \mathrm{K}^{-1}\right), \mathrm{V}_{\mathrm{m}}$ is the molar volume of the specific gas ( 22.3 for $\mathrm{CO}_{2}$ and $\mathrm{CH}_{4}$, and 22.2432 for $\mathrm{N}_{2} \mathrm{O}$ ) and $\mathrm{V}_{\text {ideal }}=22.4136 \mathrm{~mol} \cdot \mathrm{L}^{-1}$ is the molar volume of ideal gases. Solubility coefficients were estimated from the Virial expansion (Eq. 3), where B was $\beta$ or $\beta / V_{m}$, depending on which gas it was applied to (Table 3.2.2 in Sarmiento and Gruber (2013)). Our software automatically detected the gas from the $a_{i}$ coefficient. When $B=\beta$ the $k_{H}$ was estimated from Eq. (4). When $B=\beta / V_{m}$ the $k_{H}$ was estimated from Eq. (5).

$$
\begin{aligned}
& f=\exp \left(\frac{101.325 P\left(V_{m}-V_{\text {ideal }}\right)}{\mathrm{RT}_{w}}\right) \\
& \log \frac{p_{H_{2} O}}{P}=24.4543-67.4509\left(\frac{100}{T_{w}}\right)-4.8489 \ln \left(\frac{T_{w}}{100}\right)-0.000544 S \\
& \log (B)=a_{1}+a_{2} \frac{100}{T_{w}}+a_{3} \log \frac{T_{w}}{100}+a_{4}\left(\frac{T_{w}}{100}\right)^{2} \\
& \quad+S \cdot\left(b_{1}+b_{2} \frac{T_{w}}{100}+b_{3}\left(\frac{T_{w}}{100}\right)^{2}\right) \\
& k_{H}=\left(1-\frac{p_{H_{2} O}}{P}\right) \frac{101.325 V_{m}}{\mathrm{RT}_{w} \beta f} \\
& k_{H}=\frac{101.325}{\mathrm{RT}_{w} \beta f}
\end{aligned}
$$

Johnson (2010) developed an algorithm from an alternative chemistry background. It accounts for the effects of temperature and salinity taking into consideration the molecular and thermodynamic properties of the water, its solutes and the specified gas, but disregarding the non-ideal behaviour of the gases and moisture. His formulation was developed from the compilation by Sander (2015) (although available in the web since 1999) of the $\mathrm{k}_{\mathrm{H}} \mathrm{cp}$ for nearly all

110 gases in the atmosphere at $25^{\circ} \mathrm{C}(298.15 \mathrm{~K})$ and 0 ppt. Then, equation (6) converted the $\mathrm{k}_{\mathrm{H}} \mathrm{cp}$ to $\mathrm{k}_{\mathrm{H}}$ at a given temperature and 0 ppt salinity. The term $-\Delta_{\text {soln }} \mathrm{H} / \mathrm{R}$ reflected the temperature (in Kelvin) dependence of solubility, having a value of 2400 for $\mathrm{CO}_{2}, 1700$ for $\mathrm{CH}_{4}$ and 2600 for $\mathrm{N}_{2} \mathrm{O}$. The correction to a given salinity (Eq. 7) relied on the 
Geosci. Model Dev. Discuss., doi:10.5194/gmd-2016-273, 2016

Manuscript under review for journal Geosci. Model Dev.

Published: 23 November 2016

(c) Author(s) 2016. CC-BY 3.0 License.

empirical Setschenow constants $\left(\mathrm{K}_{\mathrm{S}}=\theta \cdot \log \mathrm{Vb}\right)$ reporting the effect of electrolytes salting-out gases proportionally to their liquid molar volume at boiling point $(\mathrm{Vb})$. The $\mathrm{Vb}$ was estimated using the additive Schroeder method, whereas $\theta$

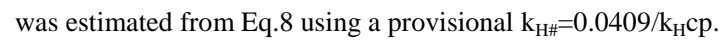

$$
\begin{aligned}
k_{H, 0}=\frac{12.1866}{P \cdot T_{W} \cdot k_{H, \mathrm{cp}} \cdot e^{\frac{-\Delta_{\mathrm{Soln} H} H}{R}\left(1 T_{W}-1298.15\right)}} \\
k_{H}=k_{H, 0} \cdot 10^{K_{S} S} \\
\theta=7.33532 \cdot 10^{-4}+3.39615^{*} 10^{-5} \cdot \log \left(k_{\mathrm{H} \#}\right) \\
\quad-2.40888 \cdot 10^{-6} \cdot \log \left(k_{\mathrm{H} \#}\right)^{2} \\
+1.57114 \cdot 10^{-7} \cdot \log \left(k_{\mathrm{H} \#}\right)^{3}
\end{aligned}
$$

\subsection{Transfer velocity}

The available algorithms consider that the rate at which gases cross the sea-surface is basically set by the turbulence upon it. E.g. wind drag, wave breaking, currents and rain promote turbulence. The water viscosity, set by temperature and salinity and enhanced by the presence of surfactants, antagonizes turbulence. With all these forcings, it becomes difficult to develop an algorithm that estimates the transfer velocity accurately. The literature has many of them, either fitted to specific surface conditions or rougher generalizations, focusing on different factors and relying in different theoretical backgrounds. The simpler ones rely on the wind velocity $10 \mathrm{~m}$ above the sea-surface $\left(\mathrm{u}_{10}\right)$. Among then, the formulation by Wanninkhof (1992) (henceforth also mentioned as 'Wan92') became the standard used in ESM and satellite data processing. It further considers the $\mathrm{Schmidt}$ number of the water $\left(\mathrm{Sc}_{\mathrm{w}}\right)$ related to viscosity and with its exponent reflecting the surface layer's rate of turbulent renewal, and the temperature dependent chemical enhancement due to $\mathrm{CO}_{2}$ reaction with water $\left(\alpha_{\mathrm{Ch}}\right)$ :

$$
\begin{aligned}
& k_{w}=\left(\alpha_{\mathrm{Ch}}+0.31 \cdot u_{10}^{2}\right)\left(\frac{\mathrm{Sc}_{w}}{660}\right)^{-0.5} \\
& \alpha_{\mathrm{Ch}}=2.5 \cdot\left(0.5246+0.0162 T_{w}+0.000499 T_{w}^{2}\right)
\end{aligned}
$$

Other simple empirical formulations based only on $\mathrm{u}_{10}$ (Carini et al., 1996; Raymond and Cole, 2001), or also accounting for current drag with the bottom (Borges et al., 2004), used data collected in estuaries under low wind conditions. However, modelling the coastal ocean at finer resolutions requires an enhanced representation of the multitude of processes involved. Hence, we updated the framework by Vieira et al. (2013), with the $\mathrm{k}_{\mathrm{w}}$ being decomposed into its shear produced turbulence $\left(\mathrm{k}_{\text {wind }}\right)$ and bubbles from whitecapping $\left(\mathrm{k}_{\text {bublle }}\right)$ forcings (Asher and Farley, 1995; Borges et al, 2004; Woolf, 2005; Zhang et al., 2006). The effect of currents was disregarded at this stage (Eq. 10). $\mathrm{Sc}_{\mathrm{w}}$ was determined from temperature and salinity following Johnson (2010).

$k_{w}=\left(\alpha_{\mathrm{Ch}}+k_{\mathrm{bubble}}+k_{\mathrm{wind}}\right) \cdot\left(600 / \mathrm{Sc}_{w}\right)^{0.5}$

The formulation by Zhao et al. (2003), merged $\mathrm{k}_{\text {wind }}$ into $\mathrm{k}_{\text {bubble }}$ (Eq. 11a) using the wave breaking parameter $\left(\mathrm{R}_{\mathrm{B}}\right.$ given by Eq. $11 b$ ). The $u_{*}$ is the friction velocity i.e, the velocity of wind dragging on the sea-surface, and $f_{p}$ is the peak angular frequency of the wind-waves. The kinematic viscosity of air $\left(v_{\mathrm{a}}\right)$ was estimated from Johnson (2010). This 
Geosci. Model Dev. Discuss., doi:10.5194/gmd-2016-273, 2016

Manuscript under review for journal Geosci. Model Dev.

Published: 23 November 2016

(c) Author(s) 2016. CC-BY 3.0 License.

solution used the wave field as a proxy for whitecapping that increased transfer velocity with wind-wave age. However,

$k_{\text {bubble }}=0.1315 \cdot R_{B}^{0.6322}$

$R_{B}=\frac{u_{*}^{2}}{2 \pi f_{p} v_{a}}$

155

A more comprehensive solution split the two drives of transfer velocity (Woolf, 2005; Zhang et al., 2006): $\mathrm{k}_{\text {wind }}$ for the transfer mediated by the turbulence generated by wind drag (Eq. 12) (Jähne et al., 1987) and $\mathrm{k}_{\text {bubble }}$ for the transfer mediated by the bubbles generated by breaking waves (Eq. 13) (Zhang et al., 2006). B is Bunsen's solubility coefficient estimated for the local sea-surface conditions. $\mathrm{W}=3.88 \times 10^{-7} \mathrm{R}_{\mathrm{B}}{ }^{1.09}$ is the whitecap cover requiring the $\mathrm{R}_{\mathrm{B}}$ estimated from (Eq. 11b), V=4900, e=14 and $n=1.2$.

$k_{\mathrm{wind}}=1.57 \cdot 10^{-4} \cdot u_{*}$

$k_{\text {bubble }}=\frac{\mathrm{wV}}{B}\left[1+\left(e \cdot B \cdot \mathrm{Sc}_{w^{-12}}\right)^{-1 n}\right]^{-n}$

These formulations required friction velocity $\left(\mathrm{u}_{*}\right)$, which was estimated from the Wind Log-Linear Profile (WLLP: Eq. 14) accounting for wind speed at height $\mathrm{z}\left(\mathrm{u}_{\mathrm{z}}\right)$, atmospheric stability of the surface boundary layer (through $\psi_{\mathrm{m}}$ ) and seasurface roughness (through the roughness length $\mathrm{z}_{0}$ ). The $\kappa$ is von Kármàn's constant.

$u_{*}=\frac{u_{z} \cdot \kappa}{\ln (z)-\ln \left(z_{0}\right)+\psi_{m}\left(z, z_{0}, L\right)}$

Roughness length $\left(\mathrm{z}_{0}\right)$ is the theoretical minimal height (most often sub-millimetrical) at which wind speed averages zero. It is dependent on surface roughness and often used as its index. It is more difficult to determine over water than over land as there is a strong bidirectional interaction between wind and sea-surface roughness. Taylor and Yelland (2001) proposed a dimensionless $z_{0}$ dependency from the wave field, increasing with the wave slope (Eq. 15). Due to the bidirectional nature of the $\mathrm{z}_{0}$ and $\mathrm{u}_{*}$ relation, we also tested an iterative solution (iWLP) where Eq.15 was used as a first guess for the $z_{0}$ and Eq.14 for its subsequent $u_{*}$. A second iteration re-estimated $z_{0}$ from the COARE 3.0 (Fairall et al.; 2003) adaptation of the Taylor and Yelland (2001) formulation, which added a term for smooth flow (Eq. 16), and $\mathrm{u}_{*}$ again from Eq.14. Applying four iterations were enough for an excellent convergence of the full data array.

$z_{0}=1200 \cdot H_{s}\left(\frac{H_{s}}{L_{p}}\right)^{4.5}+\frac{0.11 v_{a}}{u_{*}}$

Atmospheric stability characterized the tendency of the surface boundary layer (SBL) to be well mixed (unstable SBL with $\psi_{\mathrm{m}}<0$ ) or stratified (stable SBL with $\psi_{\mathrm{m}}>0$ ). It was inferred from the 'bulk Richardson number' (Ri $\mathrm{b}_{\mathrm{b}}$ : Eq. 17), weighting the air vertical heat gradient and kinetic energy. Its estimation required the air virtual potential temperature, 
Geosci. Model Dev. Discuss., doi:10.5194/gmd-2016-273, 2016

Manuscript under review for journal Geosci. Model Dev.

Published: 23 November 2016

(c) Author(s) 2016. CC-BY 3.0 License.

in its turn estimated from air temperature, air pressure and specific humidity (Grachev and Fairall, 1997) or from the liquid water mixing ratio (Stull, 1988). Alternatively, the use of the air potential temperature neglected humidity (Lee, 1997). The wind velocity $\left(\mathrm{u}_{\mathrm{z}}\right)$, temperature $\left(\mathrm{T}_{\mathrm{z}}\right)$, pressure $\left(\mathrm{P}_{\mathrm{z}}\right)$ and humidity $\left(\mathrm{q}_{\mathrm{z}}\right) \mathrm{z}$ meters above sea-surface were given by the WRF second level. The wind velocity at $\mathrm{z}_{0}\left(\mathrm{u}_{0}\right)$ was set to the theoretical $\mathrm{u}_{0}=0$. Temperature at the height of $0 \mathrm{~m}$ $\left(\mathrm{T}_{0}\right)$ was given by the SST (Grachev and Fairall, 1997; Fairal et al., 2003; Brunke et al., 2008) without rectification for cool-skin and warm-layer effects due to the lack of some required variables. Yet, these effects tend to compensate each other (Brunke et al., 2008; Fairall et al., 1996; Zeng and Beljars, 2005). Air pressure at $0 \mathrm{~m}\left(\mathrm{P}_{0}\right)$ was given by the WRF at the lower first level (at roughly $0 \mathrm{~m})$. Humidity at $0 \mathrm{~m}\left(\mathrm{q}_{0}\right)$ was set to the saturation level at $\mathrm{P}_{0}$ and $\mathrm{T}_{0}($ Grachev and Fairall, 1997). The $\mathrm{Ri}_{\mathrm{b}}$ was used to estimate the length $\mathrm{L}$ from, Monin-Obukhov's similarity theory, a discontinuous exponential function tending to $\pm \infty$ when $\mathrm{Ri}_{\mathrm{b}}$ tends to \pm 0 and tending to \pm 0 when $\mathrm{Ri}_{\mathrm{b}}$ tends to $\pm \infty$. $\mathrm{Ri}_{\mathrm{b}}$ and $\mathrm{L}$ were used to estimate $\psi_{\mathrm{m}}$ following Stull (1988) or Lee (1997) algorithms.

$\mathrm{Ri}_{b}=\frac{g \Delta T \Delta z_{i}}{T \cdot u_{z}^{2}}$

$\mathrm{CO}_{2}$ is mildly soluble with a $\mathrm{K}_{\mathrm{H}}=1.17$ for pure water at $25^{\circ} \mathrm{C}$. Its transfer velocity is limited by the molecular crossing of the water-side surface layer. $\mathrm{CH}_{4}$ is much less soluble with a $\mathrm{K}_{\mathrm{H}}=31.5$ for pure water at $25^{\circ} \mathrm{C}$. Its transfer velocity should also take into consideration the molecular crossing of the air-side surface layer (Johnson, 2010). We compared between the use of the traditional single layer and the double layer "thin film" model (Liss and Slater, 1974; Johnson, 2010; Vieira et al, 2013), the later requiring the air-side transfer velocity $\left(\mathrm{k}_{\mathrm{a}}\right)$ estimated from the COARE formulation as in Eq. 18 (Jeffrey et al., 2010). CD is the drag coefficient and $\mathrm{Sc}_{\mathrm{a}}$ the Schmidt number of air, which were determined for a given temperature and salinity following Johnson (2010).

$k_{a}=\frac{u_{*}}{13.3 \cdot \mathrm{Sc}_{a}^{12}+\mathrm{CD}^{12}-5+\frac{\log (\mathrm{Sc} a)}{2 \kappa}}$

\subsection{Validation with field data}

The field sampling occurred from the $22^{\text {nd }}$ of May 2014 to the $26^{\text {th }}$ of May 2014 using the atmospheric tower at Östergarnsholm in the Baltic Sea $\left(57^{\circ} 27^{\prime} \mathrm{N}, 18^{\circ} 59^{\prime} \mathrm{E}\right)$, the Submersible Autonomous Moored Instrument ( $\left.\mathrm{SAMI}-\mathrm{CO}_{2}\right)$ $1 \mathrm{~km}$ away and the Directional Waverider (DWR) $3.5 \mathrm{~km}$ away, both south-eastward from the tower (see e.g. Högström et al. (2008) and Rutgersson et al. (2008) for detailed description of the sites). The air-water $\mathrm{CO}_{2}$ fluxes measured by eddy-covariance were smoothed over $30 \mathrm{~min}$ bins and corrected according to the Webb-Pearman-Leuning (WPL) method (Webb et al., 1980). We used only the fluxes for which the wind direction set the $\mathrm{SAMI}_{-} \mathrm{CO}_{2}$ and DWR in the footprint of the atmospheric tower $\left(90^{\circ}<\right.$ wind direction $\left.<180^{\circ}\right)$. The DWR measured temperatures at $0.5 \mathrm{~m}$ depth, taken as representative for the sea-surface. Salinity was obtained from the Asko mooring data provided by the Baltic In-Situ Near-Real-Time Observations available in Copernicus Marine catalogue. We applied this data set to the single processing software ensemble of the FuGas 2.1 in order to test which algorithms provide better approximations to reality. 
Geosci. Model Dev. Discuss., doi:10.5194/gmd-2016-273, 2016

Manuscript under review for journal Geosci. Model Dev.

Published: 23 November 2016

(c) Author(s) 2016. CC-BY 3.0 License.

\subsection{Atmosphere-ocean coupler}

The atmospheric model was the standard operational application of the WRF by Meteodata.cz, with $9 \mathrm{~km}$ and $1 \mathrm{~h}$ resolutions. Air temperature ' $\mathrm{T}$ ' $\left({ }^{\circ} \mathrm{C}\right)$, pressure ' $\mathrm{P}$ ' ( $\left.\mathrm{atm}\right), \mathrm{U}$ and $\mathrm{V}$ components of wind velocity $\left(\mathrm{m} \cdot \mathrm{s}^{-1}\right)$, water vapour mixing ratio 'Q' (scalar) and height ' $h$ ' $(\mathrm{m})$, where retrieved at the two lowest levels within the atmospheric surface boundary layer (SBL). The vertical thickness of the WRF horizontal layers varied with space and time. Over the ocean, the two lowest levels occurred roughly at $0 \mathrm{~m}$ and $12 \mathrm{~m}$ heights. The WRF output decomposes height, temperature and pressure into their base level plus perturbation values.

Sea-surface temperature (SST) and salinity (S) were estimated by the NEMO modelling system provided in the MyOcean catalogue with $1 / 12^{\circ}$ and 1 day resolutions. The WW3 wave field data for the Mediterranean Sea was supplied by INGV using the WW3-NEMO modelling system at $0.0625^{\circ}$ and $1 \mathrm{~h}$ resolutions (Clementi, 2013), and for the North Atlantic by Windguru at roughly $0.5^{\circ}$ and $3 \mathrm{~h}$ resolutions. The variables included significant wave height ' $\mathrm{H}_{\mathrm{s}}$ ' (m) and peak frequency ' $f_{p}$ ' $\left(r a d \cdot s^{-1}\right)$ for wind sea i.e, disregarding swell. A few aspects did not correspond to the ideal data format for atmosphere-ocean coupling, and required further calculations: (i) The peak wave length ' $\mathrm{L}_{\mathrm{p}}$ ' (m) was estimated from the peak frequency assuming the deep-water approximation: $L_{p}=2 \pi g / f_{p}{ }^{2}$, where $g$ is the gravitational acceleration constant; (ii) the Windguru data did not provide wind sea component (where and) when the wind was too low. For these missing cases were attributed the lowest $\mathrm{H}_{\mathrm{s}}$ and $\mathrm{L}_{\mathrm{p}}$ simulated everywhere else; (iii) the Windguru and the INGV data overlapped along the Iberian shores, in which case the INGV was given a 2:1 weight over the Windguru data.

The WRF and WW3-Nemo outputs were retrieved for the European shores from the $24^{\text {th }}$ of May 2014 at $06 \mathrm{~h}$ to the $27^{\text {th }}$ of May 2014 at $00 \mathrm{~h}$. All variables were interpolated to the same $0.09^{\circ}$ grid (roughly $11 \mathrm{~km}$ at Europe's latitudes) and $1 \mathrm{~h}$ time steps. This resulted in a data set with 17 variables $\times 41776$ locations $\times 66$ time instances, that occupied nearly $1 \mathrm{~Gb}$ ram memory (with another $1 \mathrm{~Gb}$ taken by the software). To optimize the computations, the calculus was first vectorized and then parallelized using the Single Program Multiple Data (spmd) programming strategy. Hence, in the FuGas 2.1 multiple processing software ensemble, the variables were first organized in matrices with locations along the $1^{\text {st }}$ dimension and time along the $2^{\text {nd }}$. Running the calculus applying matrix algebra to the whole data set, by itself represented an improved speed of several orders of magnitude. Furthermore, the spmd replicated the data, split the replicates into $\mathrm{n}$ approximately equal-sized arrays, and distributed their calculus among the $\mathrm{n}$ available cpu cores, which represented an extra improvement of computational speed. However, it also bared computational costs: (i) invoking the parallel processing toolbox was time consuming, (ii) replicating $1 \mathrm{~Gb}$ ram was time consuming, (iii) once running the calculus, the 4Gb ram memory was soon exhausted, which stall the calculus, (iv) to avoid it, the spmd were split into several sequential code blocks and in-between the variables no longer necessary were deleted. This spmd fragmentation was time consuming. In conclusion, there is no perfect solution for calculus parallelization, and although spmd is the best strategy available for this task, its application needs to be carefully programmed according to the data and hardware characteristics.

\section{$3 \quad$ Results}

Both solubility formulations were tested simulating $\mathrm{T}_{\mathrm{w}}$ from $4^{\circ} \mathrm{C}$ to $30^{\circ} \mathrm{C}$ at $1^{\circ} \mathrm{C}$ intervals and $\mathrm{S}$ from 0 ppt to 36 ppt at 1 ppt intervals. The metric $\mathrm{k}_{\mathrm{H}, \mathrm{J} \text { oh } 10} / \mathrm{k}_{\mathrm{H}}, \mathrm{Sar} 13$ showed better how much their estimates could diverge (Fig. 1). Afterwards, both formulations were applied to the data from the European coastal ocean. Their estimates were compared applying 
Geosci. Model Dev. Discuss., doi:10.5194/gmd-2016-273, 2016

Manuscript under review for journal Geosci. Model Dev.

Published: 23 November 2016

(c) Author(s) 2016. CC-BY 3.0 License.

the previous metric averaged over the $66 \mathrm{~h}$ time interval using the geometric mean (Fig. 1). From the $24^{\text {th }}$ to the $26^{\text {th }}$ May the water temperature at the ocean surface changed significantly and there were large fresh water inputs from the Black Sea and the Baltic Sea (Video 1). The widest divergences were up to $4.5 \%$ in the $\mathrm{CO}_{2}$ solubility estimates associated to cooler waters, $5.8 \%$ in the $\mathrm{CH}_{4}$ solubility estimates associated to both temperature extremes, and $2.1 \%$ in the $\mathrm{N}_{2} \mathrm{O}$ solubility estimates associated to cooler and less saline waters (Fig. 1). These mismatches lead to large differences in the estimates of greenhouse gases dissolved in the first meter below the ocean surface (Fig. 2). These differences were estimated from $\Delta$ ton $\cdot \mathrm{m}^{-1} \cdot 121 \mathrm{~km}^{-2}=11^{2} \cdot \Delta \mathrm{s} \cdot \mathrm{p}_{\mathrm{gas}} \cdot \mathrm{P} \cdot 101325 \cdot \mathrm{M}_{\mathrm{a}} /\left(10^{9} \cdot \mathrm{R} \cdot \mathrm{T}\right)$, where $\Delta \mathrm{s}$ was the difference in the solubility estimated by either algorithm in its $\mathrm{C}_{\mathrm{w}} / \mathrm{C}_{\mathrm{a}}$ form at each $11 \mathrm{~km}$ wide cells and averaged over the $66 \mathrm{~h}$ time interval. $\mathrm{M}_{\mathrm{a}}=28.97$ was the air molecular mass and $\mathrm{p}_{\text {gas }}$ the atmospheric partial pressure of $\mathrm{CO}_{2}, \mathrm{CH}_{4}$ or $\mathrm{N}_{2} \mathrm{O}, 390 \mathrm{ppm}$, $1.75 \mathrm{ppm}$ and $0.325 \mathrm{ppm}$ respectively (EPA, 2015), assuming that they were approximately uniform all over the atmospheric SBL. These differences summed to $3.86 \times 10^{6}$ ton of $\mathrm{CO}_{2}, 880.7$ ton of $\mathrm{CH}_{4}$ and 401 ton of $\mathrm{N}_{2} \mathrm{O}$. Because the bias of $\mathrm{N}_{2} \mathrm{O}$ changed from positive to negative with location, the overall bias was 163 ton.

The $\mathrm{k}_{\mathrm{w}}$ estimated from the E-C measurements presented a systematic bias. To detect its source, the difference $\left(\Delta \mathrm{k}_{\mathrm{w}}\right)$ between the $\mathrm{k}_{\mathrm{w}}$ estimated from the E-C measurements and the one estimated from the Wan92 formulation was compared to the potential sources of bias. Besides well correlated with $\mathrm{u}_{10}(\mathrm{r}=0.55)$, the $\Delta \mathrm{k}_{\mathrm{w}}$ was also well correlated with the relative humidity ( $r=-0.7)$ and with the first $(r=0.49)$, second $(r=0.47)$ and third $(r=0.67)$ terms of the WPL correction. The distortion of the E-C flux estimates by cross-sensitivity to humidity is a common problem with openpath IRGA, raising substantially their detection limit. The observed differences between the concentrations of $\mathrm{CO}_{2}$ in the air and in the water during our survey varied within 120 and $270 \Delta \mathrm{ppm}$, well below the limit for a $25 \%$ error in the flux estimates as reported by Blomquist et al. (2014) for our IRGA model, the LI-COR LI-7500. We hypothesize whether the E-C data lacked quality to calibrate and validate the formulations. However, our formulations were close matches to the estimates by widely used transfer velocity formulations subject to thorough calibration and validation, which proved them reasonable estimators of the central tendency (Fig. 3). Hence, we were confident about the potential of our newly proposed formulations to replicate the central tendency similarly well while improving the accuracy of the estimates for each particular location.

During this Baltic Sea sampling at the Östergarnsholm site, the SBL was generally stable $\left(0<\mathrm{Ri}_{\mathrm{b}}<0.5\right.$ with a few exceptions) and the sea-surface was little to moderately rough $\left(\mathrm{z}_{0}<0.49 \mathrm{~mm}\right)$. These conditions were used as reference to estimate the elasticity of $\mathrm{k}_{\mathrm{w}}$ to its forcing functions (Fig. 4). The variables related with the SBL stability, namely the $\mathrm{u}_{10}$, temperature, pressure and humidity, were the variables able to induce larger changes in $\mathrm{k}_{\mathrm{w}}$. Several renowned $\mathrm{u}_{10}$-based formulations for the estimation of $\mathrm{k}_{\mathrm{w}}$ were used and compared with the most comprehensive alternatives provided in our software and framework (Fig. 3). Although their estimates were close matches, there were a few fundamental differences: the comprehensive algorithms split the data points into two distinct scatter lines, the upper line for $\mathrm{k}_{\mathrm{w}}$ obtained under rougher sea-surfaces and the lower line for $\mathrm{k}_{\mathrm{w}}$ obtained under smother ones. The red markers representing the ZRb03 iWLP give the best example. The $\mathrm{u}_{10}$-based formulations were unable to perform this adjustment to the local wave state. Their small $\mathrm{k}_{\mathrm{w}}$ fluctuations were a sole consequence of changes in water viscosity (as estimated by the $\mathrm{Sc}_{\mathrm{w}}$ ) driven by changes in water temperature. These results highlight the potential of the SBL stability and the sea-surface agitation as additional $\mathrm{k}_{\mathrm{w}}$ mediators. It is curious that the wave variables were the responsible for the big differences between $\mathrm{k}_{\mathrm{w}}$ estimates (as shown in Fig. 3) although these were the variables to which the $\mathrm{k}_{\mathrm{w}}$ was least elastic (as shown in Fig. 4). It demonstrates that more important than model sensitivity (or elasticity) is how much the 
Geosci. Model Dev. Discuss., doi:10.5194/gmd-2016-273, 2016

Manuscript under review for journal Geosci. Model Dev.

Published: 23 November 2016

(c) Author(s) 2016. CC-BY 3.0 License.

respective variables effectively change in the real world. There is yet the interesting detail of how the WLLP and the iWLP diverged under smoother sea-surfaces, supporting the solution suggested in the COARE 3.0 (Fairall et al., 2003) for the iterative estimation of $\mathrm{u}_{*}$ and $\mathrm{z}_{0}$.

Complementary to the analysis above, we also used the simulations of the European costal oceans to compare between the ESM standard (the Wan92) and one of our comprehensive alternatives (the iWLP-ZRb03), chosen on the basis of two factors: it was both the most elastic formulation and the one providing the closest estimates to the Wan92 (recall Fig. 3). Since the Wan92 often represented the central tendency of the iWLP-ZRb03, this choice provided the best probability that the differences between the $\mathrm{k}_{\mathrm{w}}$ estimates were due to the enhanced representation of the environmental processes involved and not to systematic biases associated to uncertainty in the parameter estimation. Both $\mathrm{k}_{\mathrm{w}}$ estimates diverged under two particular situations (Fig. 5): (i) under low winds and unstable SBL, and (ii) under high winds and rougher sea-surfaces.

Strong winds occurred along the European shores from the $24^{\text {th }}$ to the $26^{\text {th }}$ of May of 2014. Besides, the air was unusually cold for the season and colder than the sea-surface (Video 1). The upward advection of the warmer air, heated by the sea-surface, generated turbulent eddies that enhanced mixing within the SBL. These unstable conditions were identified by $\mathrm{Ri}_{\mathrm{b}}<0$, L tending to 0 and $\psi_{\mathrm{m}}<0$ (Video 2). The mixing of the SBL enhanced $\mathrm{u}_{*}$ and $\mathrm{k}_{\mathrm{w}}$ everywhere the wind blew lighter. This situation occurred more frequently and intensively nearby land masses and often associated to cooler continental breezes blowing off-shore. Its correct simulation required the estimation of the $\mathrm{Ri}_{\mathrm{b}}, \mathrm{L}$ and $\psi_{\mathrm{m}}$ from the algorithms by Grachev and Fairall (1997) and Stull (1988) that account for humidity considering saturation at $0 \mathrm{~m}$ heights. The $\mathrm{Ri}_{\mathrm{b}}$ estimates neglecting humidity (Lee, 1997) often yielded neutral conditions (i.e, with $\mathrm{Ri}_{\mathrm{b}} \approx 0$ ) or unreasonably stable $\mathrm{SBL}$ (i.e, with $\mathrm{Ri}_{\mathrm{b}}>0$ ).

The sea-surface agitation was very heterogenic, particularly at the coastal ocean where it attained both the highest and the lowest estimated roughness lengths (the $\mathrm{z}_{0}$ in Video 3). There, the steeper waves as a consequence of shorter fetches, should extract more momentum from the atmosphere under similar $\mathrm{u}_{10}$ conditions (Taylor and Yelland, 2001; Fairall et al, 2003). Thus, the rougher coastal ocean surfaces were expected to possess more turbulent layers through which gases were transferred at higher rates. The comprehensive formulations simulated this by increasing $\mathrm{u}_{*}$ (and consequently $\mathrm{k}_{\mathrm{wind}}$ ) with $\mathrm{z}_{0}$ under similar $\mathrm{u}_{\mathrm{z}}$ i.e, similar winds generate more drag when blowing over harsher seasurfaces. Aside the rougher weather, whenever lighter wind blew over smoother sea-surfaces, the iWLP estimated much higher $\mathrm{z}_{0}$ than the WLLP (video 4), demonstrating that the smooth flow was a fundamental driver for the $\mathrm{z}_{0}$ under calmer weather. This increase in $\mathrm{z}_{0}$ lead to significantly higher $\mathrm{u}_{*}$, often 1.5 times higher and sometimes more, anticipating a significant impact on the $\mathrm{k}_{\mathrm{wind}}$ estimates.

The comprehensive formulation (i.e, ZRb03 iWLP) often estimated $\mathrm{k}_{\mathrm{w}}$ largely higher than the one estimated by the ESM standard formulation (i.e, Wan92), although it occasionally estimated lower $\mathrm{k}_{\mathrm{w}}$ (Video 5). Its largest estimates of $\mathrm{k}_{\mathrm{w}}$ were associated to unreasonably high estimates of $\mathrm{z}_{0}$ that biased the subsequent results. These biased estimates of $z_{0}$ could either be due to a poor calibration of the Taylor and Yelland (2001) model estimating $z_{0}$ from the wave field or due to biased wave field provided by the WW3-NEMO. To avoid this bias, $\mathrm{k}_{\mathrm{w}}$ was imposed a $70 \mathrm{~cm} \cdot \mathrm{h}^{-1}$ ceiling, corresponding to the maximum reported in the bulk literature associated to similar wind speeds. With this restriction, the difference in the $\mathrm{CO}_{2}$ volume transferred by either formulation across the $\approx 5,054,896 \mathrm{~km}^{2}$ of ocean surface during the $66 \mathrm{~h}$ was of $12997 \mathrm{~km}^{3}$, corresponding to $33.7 \%$ of the $38551 \mathrm{~km}^{3}$ of $\mathrm{CO}_{2}$ total volume transferred using the ESM standard formulation (Fig. 6). These differences were higher at the coastal ocean, a consequence of the factors that were 
Geosci. Model Dev. Discuss., doi:10.5194/gmd-2016-273, 2016

Manuscript under review for journal Geosci. Model Dev.

Published: 23 November 2016

(c) Author(s) 2016. CC-BY 3.0 License.

not taken into consideration by the ESM standard. The total volumes of $\mathrm{CH}_{4}$ and of $\mathrm{N}_{2} \mathrm{O}$ transferred were $41156 \mathrm{Km}^{3}$ and $41158 \mathrm{Km}^{3}$, respectively. The differences were negligible between using the single layer or the double layer scheme to estimate $\mathrm{k}_{\mathrm{w}}$, even for a rather insoluble gas as is $\mathrm{CH}_{4}$ (Fig. 6 and Video 5). Nevertheless, it is worth noting that it was again in the fetch limited coastal ocean where most of the bigger differences were found.

\section{Discussion}

The accurate estimation of the balances of greenhouse gases and aerosols in the atmosphere and in the oceans, as well as their fluxes across the surfaces of the coastal oceans, is an important issue for biogeosciences and Earth-System modelling (ESM). Previous estimates of $\mathrm{CO}_{2}$ uptake by the global oceans done by coarse resolution implementations diverged in about $70 \%$ depending on the transfer velocity formulations being used (Takahashi et al., 2002), whereas the wide uncertainty in the ocean $\mathrm{N}_{2} \mathrm{O}$ source to the atmosphere mostly originated from the uncertainty in the air-water transfer velocities (Nevison et al., 1995). However, the knowledge on this subject is still limited, with plenty of room for improvement. As an example, the simpler formulations for the estimation of $\mathrm{k}_{\mathrm{w}}$ assume either a quadratic or cubic dependency from $\mathrm{u}_{10}$ depending mostly on the sensing method, time scale and fetch at the particular location.

Furthermore, the simulation of atmosphere-ocean interactions by regional and Earth-system models, by still using these simpler formulations, are decades behind the state-of-the-art. Our work proposes a framework to incorporate this stateof-the-art in an atmosphere-ocean coupler and demonstrates that this is fundamental for reliable simulations of coastal ocean systems.

Remarkably, both solubility formulations generally matched their estimates despite their distinct backgrounds. Nevertheless, they did diverge in as much as $0.045 \mathrm{~mol} \cdot \mathrm{mol}^{-1}$ of $\mathrm{CO}_{2}, 0.0015 \mathrm{~mol} \cdot \mathrm{mol}^{-1}$ of $\mathrm{CH}_{4}$ and $0.012 \mathrm{~mol} \cdot \mathrm{mol}^{-1}$ of $\mathrm{N}_{2} \mathrm{O}$ (i.e, mol of gas in the ocean surface per mol of gas in the atmosphere) in some of the most sensitive situations for Earth-System modelling and satellite data processing: (i) the cooler marine waters occur closer to the poles, where the solubility pump traps greenhouse gases and carries them to the deep ocean (Sarmiento and Gruber, 2013), and (ii) the warmer and the less saline waters occurring at the coastal ocean and seas, which have regularly been observed having greenhouse gases and aerosols dissolved in concentrations highly unbalanced with those of the atmosphere (Nevison et al., 2004; Borges et al, 2005; Barnes and Upstill-Goddard, 2011; Sarmiento and Gruber, 2013; Dutta et al., 2015;

Gypens and Borges, 2015; Harley et al., 2015). Therefore, the biases in the estimated total amount of greenhouse gases in the first meter depth of the European coastal ocean during late May 2014 may be an indicator of higher global biases.

This work showed that the accurate estimation of the transfer velocity of greenhouse gases and aerosols across the coastal oceans' surface requires taking into consideration at least the atmospheric stability of the SBL and the seasurface roughness, as recently suggested by Jackson et al. (2012) and Shuiqing and Dongliang (2016). Our results show that, by neglecting these factors, the simpler $\mathrm{u}_{10}$-based formulations tend to provide lower estimates of the transfer velocity than the provided by comprehensive formulations. Similar conclusions were achieved by Jackson et al. (2012). However, the more comprehensive formulations still need improvement and validation. It is imperative to calibrate and validate the estimation of transfer velocity from friction velocity and wind-wave breaking, and the roughness length from the wave field. All the available formulations for these specific purposes lack robust parameter estimations. Generally, there seems to be a great dependency of the available algorithms from the particular data sets that were used to calibrate them. Nevertheless, there is a general consensus that the $\mathrm{k}_{\text {bubble }}$ term is fundamental under high wind speeds, with its estimate being central to current $\mathrm{k}_{\mathrm{w}}$ research. The latest developments have been on the dependency of $\mathrm{k}_{\text {bubble }}$ 
Geosci. Model Dev. Discuss., doi:10.5194/gmd-2016-273, 2016

Manuscript under review for journal Geosci. Model Dev.

Published: 23 November 2016

(c) Author(s) 2016. CC-BY 3.0 License.

380 from the interactions among the wind, the wave state, the bubble plume and the properties of the gas being transferred (Woolf et al. 2007; Callaghan et al., 2008, 2014; Goddijn-Murphy et al., 2011, Crosswell, 2015). The effect of sea-spray is the new buzz on this topic and only recently started emerging algorithms like the ones by Zhao et al. (2006) and Wu et al. (2015). So far, these focused on the momentum transfer from wind to the ocean surface and the attenuation of the friction velocity. It should be interesting to understand how the intrusion of the sea-spray on the atmosphere affects the transfer velocity of gases, being anticipated a process symmetrical to that of the intrusion of bubbles on the ocean. The new algorithms for the effects of surfactants are particularly concerned with the variability of the coastal ocean (Pereira et al., 2016). These no longer associate the surfactants to the Schmidt number's exponent but rather to a coefficient setting a proportional decay of $\mathrm{k}_{\mathrm{w}}$. The effect of sea-ice must take into consideration its distortion of the ocean surface and its effect upon the SBL stability (Loose et al., 2014). Our coupling solution still needs to integrate the effects of the sea-surface cool-skin and warm-layer, surfactants, rain, sea-spray and sea-ice. From these, the cool-skin and warm-layer algorithms are the only with robust calibrations and validations, mostly done under the COARE (Fairall et al., 1996; Fairal et al., 2003; Zeng and Beljars, 2005; Brunke et al., 2008). The addition of complexity to any coupling solution must be carefully thought as these cannot become intricate to the point of calculus becoming unbearable for ESM application. In particular, any algorithm demanding for-loops is unviable as it disables calculus vectorization and its coordination with parallel processing. In our software, vectorization enabled improving calculus roughly $12 \times$ faster in a single core.

Besides finding the appropriate algorithms and parameter values to be used by the coupler, there is also the issue of accurately retrieving the variables mediating the gas transfer. The results showed that the $\mathrm{k}_{\mathrm{w}}$ was most elastic to the variables related with the SBL stability, namely the $\mathrm{u}_{10}$, temperature, pressure and humidity. Although these are provided by the oceanic and atmospheric model components at courser vertical resolutions, they need to be transposed to finer vertical resolutions taking into consideration the processes occurring at the sea-surface. While the $\mathrm{u}_{10}$ is given by the atmospheric model, the water temperature needs to account for the cool-skin and warm-layer effects and the heat and humidity at the SBL need to account for their vertical fluxes over the sea-surface. The COARE algorithm is the state-of-the-art for these tasks. During most of its development it focused on E-C methods to estimate the fluxes of heat and humidity across the SBL using a framework with an intricate mathematical structure going deeper into the simulation of the geophysical process. Given its complexity, it must be quite a challenge to perform the calculus vectorization and parallelization required for the substantial improvement of computational speed and its application to ESM. Only in its latter developments did the COARE explicitly addressed the fluxes of gases and the importance of sea-surface roughness (Fairall et al, 2003; Jeffrey et al., 2010; Blomquist et al., 2006, 2014).

\section{Code and Data Availability}

Software and data related to this article provided as supplementary material. Software, data and videos related to this article available at http://www.maretec.org/en/models/fugas

\section{Acknowledgments:}

To windguru.cz for the support providing the wave data.Work funded by ERDF Funds of the Competitiveness Factors Operational Programme - COMPETE and by national funds from the FCT - Foundation for Science and Technology project UID/EEA/50009/2013. 
Geosci. Model Dev. Discuss., doi:10.5194/gmd-2016-273, 2016

Manuscript under review for journal Geosci. Model Dev.

Published: 23 November 2016

(c) Author(s) 2016. CC-BY 3.0 License.

\section{$7 \quad$ References}

Asher, W. E. and Farley, P. J.: Phase-Doppler anemometer measurement of bubble concentrations in laboratorysimulated breaking waves, J. Geophys. Res., 100C: 7045-7056, 1995.

Barnes, J. and Upstill-Goddard, R. C.: $\mathrm{N}_{2} \mathrm{O}$ seasonal distributions and air-sea exchange in UK estuaries: implications for the tropospheric $\mathrm{N}_{2} \mathrm{O}$ source from European coastal waters. J. Geophys. Res. 116, G01006, 2011.

Blomquist, B. W., Fairall, C. W., Huebert, B. J., Kieber, D. J. and Westby, G. R.: DMS sea-air transfer velocity: Direct measurements by eddy covariance and parameterization based on the NOAA/COARE gas transfer model. Geophys. Res. Lett., 33(7), L07601, doi:10.1029/2006GL025735, 2006.

Blomquist, B. W., Huebert, B. J., Fairall, C. W., Bariteau, L., Edson, J. B., Hare, J. E. and McGillis, W. R.: Advances in Air-Sea CO2 Flux Measurement by Eddy Correlation. Boundary-Layer Meteorology, 152(3):245276, 2014.

Borges, A. V., Vanderborght, J. P., Schiettecatte, L. S., Gazeau, F., Ferron-Smith, S., Delille, B. and Frankignoulle, M.:Variability of the Gas Transfer Velocity of $\mathrm{CO}_{2}$ in a Macrotidal Estuary (the Scheldt), Estuaries, 27, 593-603, 2004.

Borges, A.V., Delille, B., and Frankignoulle, M.. Budgeting sinks and sources of $\mathrm{CO}_{2}$ in the coastal ocean: Diversity of ecosystems counts, Geophys. Res. Lett., 32, L14601, doi:10.1029/2005GL023053, 2005.

Brunke, M. A, Zeng, X., Misra, V. and Beljaars, A.: Integration of a prognostic sea surface skin temperature scheme into weather and climate models. J. Geophys Res., 113, D21117, doi: 10.1029/2008JD010607, 2008.

Callaghan, A. H., Deane, G. B. and Stokes, M. D.: Observed physical and environmental causes of scatter in whitecap coverage values in a fetch-limited coastal zone. J. Geophys. Res., 113(C5), 10.1029/2007JC004453, 2008.Callaghan, A. H., Stokes, M. D. and Deane, G. B.: The effect of water temperature on air entrainment, bubble plumes, and surface foam in a laboratory breaking-wave analog. J. Geophys. Res., 113(C5), 10.1029/2007JC004453, 2008.

Carini, S., Weston, N., Hopkinson, C., Tucker, J., Giblin, A., and Vallino, J.: Gas exchange rates in the Parker River estuary, Massachusetts. Biol. Bull., 191, 333-334, 1996.

Clementi E., Oddo P., Korres G., Drudi M. and Pinardi N.: Coupled wave-ocean modelling system in the Mediterranean Sea. Extended abstract to the 13th Int. Workshop on Wave Hindcasting, Banff, Canada, 2013.

Crosswell, J. R.: Bubble clouds in coastal waters and their role in air-water gas exchange of CO2. J. Mar. Sci. Eng., 3, 866-890; doi:10.3390/jmse3030866, 2015.

Dutta, M. K., Mukherjee, R., Jana, T. K. and Mukhopadhyay, S. K.: Biogeochemical dynamics of exogenous methane in an estuary associated to a mangrove biosphere; The Sundarbans, NE coast of India. Mar. Chem., 170, 1-10, 2015.

EPA United States Environmental Protection Agency - Climate Change Indicators in the United States - Atmospheric concentrations of greenhouse gases, http://www.epa.gov/climatechange/science/indicators/ghg/ghgconcentrations.html, last accessed: 27 August 2015.

Fairall, C.W., Bradley, E. F., Godfrey, J. S., Wick G. A., Edson, J. B. and Young G. S.: Cool-skin and warm-layer effects on sea surface temperature, J. Geophys. Res., 101, 1295-1308, 1996.

Fairall, C. W., Bradley, E.F., Hare, J.E., Grachev, A.A., and Edson, J.B.: Bulk parameterization of air-sea fluxes: updates and verification for the COARE algorithm, J. Climate, 16, 571-591, 2003. 
Geosci. Model Dev. Discuss., doi:10.5194/gmd-2016-273, 2016

Manuscript under review for journal Geosci. Model Dev.

Published: 23 November 2016

(c) Author(s) 2016. CC-BY 3.0 License.

Goddijn-Murphy, L., Woolf, D. K. and Callaghan, A. H.: Parameterizations and Algorithms for Oceanic Whitecap Coverage. Journal of Physical Oceanography, 41, 742-756, 2011.

Grachev, A. A. and Fairall, C. W.: Dependence of the Monin-Obukhov Stability Parameter on the Bulk Richardson Number over the Ocean. J. Appl. Meteorol., 36, 406-414, 1997.

Gypens, N. and Borges, A. V.: Increase in dimethylsulfide (DMS) emissions due to eutrophication of coastal waters offsets their reduction due to ocean acidification, Front. Mar. Sci., 1,4. doi: 10.3389/fmars.2014.00004, 2015.

Harley, J. F., Carvalho, L., Dudley, B., Heal, K. V., Rees, R. M. and Skiba, U.: Spatial and seasonal fluxes of the greenhouse gases N2O, CO2 and CH4 in a UK macrotidal estuary, Estuar, Coast. Shelf S., 153, 62, 2015.

Högström, U., Sahlée, E., Drennan, W. M. Kahma, K. K., Smedman, A.-S., Johansson, C., Pettersson, H., Rutgersson, A., Tuomi, L, Zhang, F. and Johansson, M.: To what extent can we believe measurements on a land-based tower to represent upwind open sea conditions? Boreal Environ. Res., 13, 475-502, 2008.

Jackson, D. L., Wick, G. A. and Hare, J. E.: A comparison of satellite-derived carbon dioxide transfer velocities from a physically based model with GasEx cruise observations. J. Geophys. Res. 117, G00F13, doi:10.1029/2011JC007329, 2012.

Jähne, B., Munnich, K. O., Bosinger, R., Dutzi, A., Huber, W. and Libner, P.: On the parameters influencing air-water gas exchange. J.Geophys. Res., 92, 1937-1949, 1987.

Jeffery, C., Robinson, I., and Woolf, D.: Tuning a physically-based model of the air-sea gas transfer velocity, Ocean Modell., 31, 28-35. doi:10.1016/j.ocemod.2009.09.001, 2010.

Johnson, M. T.: A numerical scheme to calculate temperature and salinity dependent air-water transfer velocities for any gas, Ocean Sci., 6, 913-932, 2010.

Lee, H.N.: Improvement of surface flux calculations in the atmospheric surface layer, J. Appl. Meteorol., 36, 1416$1423,1997$.

Liss, P. S. and Slater, P. G.: Flux of gases across the air-sea interface, Nature, 247, 181-184, 1974.

Loose, B., McGillis, W. R., Perovich, D. Zappa, C. J. and Schlosser, P.: A parameter model of gas exchange for the seasonal sea ice zone. Ocean Sci., 10, 17-28, 2014.

Nevison, C. D., Weiss, R. F., and Erickson III, D. J.: Global oceanic emissions of nitrous oxide, J. Geophys. Res., 100, 15809-15820, 1995.

Nevison, C. D., Lueker, T. J. and Weiss, R. F.: Quantifying the nitrous oxide source from coastal upwelling. Global Biogeochem. Cy., 18, GB1018, doi:10.1029/2003GB002110, 2004.

OCMIP: Ocean Carbon-Cycle Model Intercomparison Project, available at: http://ocmip5.ipsl. jussieu.fr/OCMIP, last updated: 2004 (last access: 27 August 2015), 2004

Pereira, R., Scheneider-Zapp, K. and Upstill-Goddard, R.: Surfactant control of gas transfer velocity along an off-shore coastal transect: results from a laboratory gas exchange tank. Biogeosciences Discuss., doi:10.5194/bg-2016-7, 2016.

Raymond, P. A. and Cole, J. J.: Gas exchange in rivers and estuaries: choosing a gas transfer velocity, Estuaries, 24, 312-317, 2001.

Rutgersson, A., Norman, M., Schneider, B., Petterson, H. and Sahlée, E.: The annual cycle of carbon dioxide and parameters influencing the air-sea carbon exchange in the Baltic Proper. J. Marine Sys., 74: 381-394, 2008. 
Geosci. Model Dev. Discuss., doi:10.5194/gmd-2016-273, 2016

Manuscript under review for journal Geosci. Model Dev.

Published: 23 November 2016

(c) Author(s) 2016. CC-BY 3.0 License.

Sander, R.: Compilation of Henry's law constants (version 4.0) for water as solvent Atmos. Chem. Phys., 15, 43994981, doi:10.5194/acp-15-4399-2015, 2015.

Sarmiento, J. L. and Gruber, N.:. Ocean Biogeochemical Dynamics. Princeton University Press, New Jersey, USA. pp73-100, 2013.

Shuiqing, L. and Dongliang, Z.: Gas transfer velocity in the presence of wave breaking. Tellus B, 68, 27034, 2016.

Stull, R. B.: An introduction to Boundary Layer Meteorology, Kluwer Academic Publishers, Dordrecht, pp151-195, 1988.

Takahashi, T., Sutherland, S. C., Sweeney, C., Poisson, A., Metzl, N., Tilbrook, B., Bates, N.,Wanninkhof, R., Feelyf, R. A., Sabine, C., Olafsson, J., and Nojirih, Y.: Global sea-air CO2 flux based on climatological surface ocean $p \mathrm{CO}_{2}$, and seasonal biological and temperature effects, Deep-Sea Res., 49, 1601-1622, 2002.

Taylor, P. K. and Yelland, M. J.: The dependence of sea surface roughness on the height and steepness of the waves, J. Phys. Oceanogr., 31, 572-590. 2001.

Vieira, V. M. N. C. S., Martins, F., Silva, J. and Santos, R.: Numerical tools to estimate the flux of a gas across the airwater interface and assess the heterogeneity of its forcing functions. Ocean Sci., 9, 355-375, 2013.

Wanninkhof, R.:Relationship between wind speed and gas exchange over the ocean, J. Geophys. Res., 97, 7373-7382, 1992.

Webb, E. K., Pearman, G. I. and Leuning, R.: Correction of flux measurements for density effects due to heat and water vapour transfer. Quart. J.R. Meteorol. Soc., 106: 85-100, 1980.

Weiss, R. F.: Carbon dioxide in water and seawater: the solubility of a non-ideal gas. Mar. Chem., 2, 203-215, 1974.

Weiss, R. F. and Price B. A.: Nitrous oxide solubility in water and seawater. Mar. Chem., 8, 347-359, 1980.

Woolf, D. K.: Parameterization of gas transfer velocities and sea state-dependent wave breaking,Tellus B, 57, 87 - 94, 2005.

Woolf, D. K., Leifer, I. Nightingale, P.D., Andreae, M.O.: Modelling of bubble-mediated gas transfer: Fundamental principles and a laboratory test. J. Mar. Sys., doi: 10.1016/j.jmarsys.2006.02.011, 2007.

Wu, L., Rutgersson, A. and Sahlée, E.: The impact of waves and sea-spray on modelling storm track and development. Tellus A, 67, 27967, 2015.

Zeng, X. and Beljaars, A.: A prognostic scheme of sea surface skin temperature for modelling and data assimilation. Geophys. Res. Lett., 32, L14605, 2005.

Zhang, W., Perrie, W. and Vagle, S.: Impacts of winter storms on air-sea gas exchange. Geophys. Res. Lett., 33, L14803, 2006.

Zhao, D., Toba, Y., Suzuki, Y., and Komori, S.: Effect of wind waves on air-sea gas exchange: proposal of an overall $\mathrm{CO}_{2}$ transfer velocity formula as a function of breaking-wave parameter, Tellus B, 55, 478-487, 2003.

Zhao, D., Toba, Y., Sugioka, K. and Komori, S.: New sea spray generation function for spume droplets. J. Geophys. Res., 111(C2), doi: 10.1029/2005JC002960, 2006. 
Geosci. Model Dev. Discuss., doi:10.5194/gmd-2016-273, 2016

Manuscript under review for journal Geosci. Model Dev.

Published: 23 November 2016

(c) Author(s) 2016. CC-BY 3.0 License.

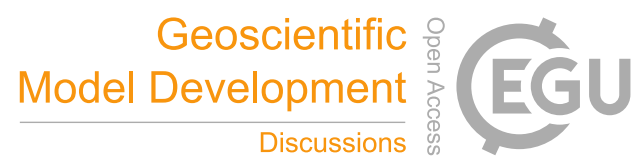

(c) $\underset{\mathrm{BY}}{\mathrm{B}}$

Figures
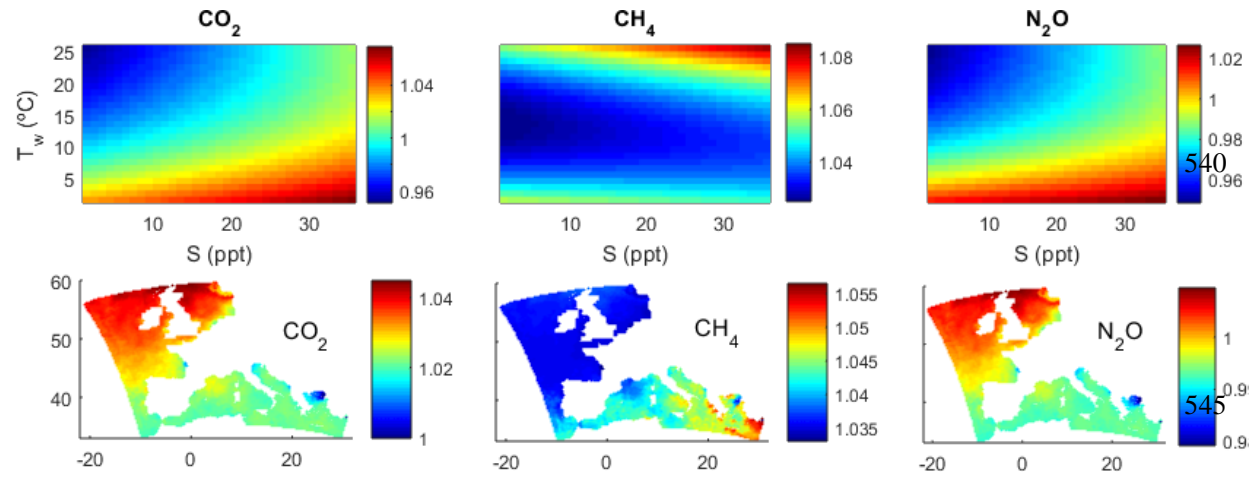

Figure 1:Comparing solubility formulations
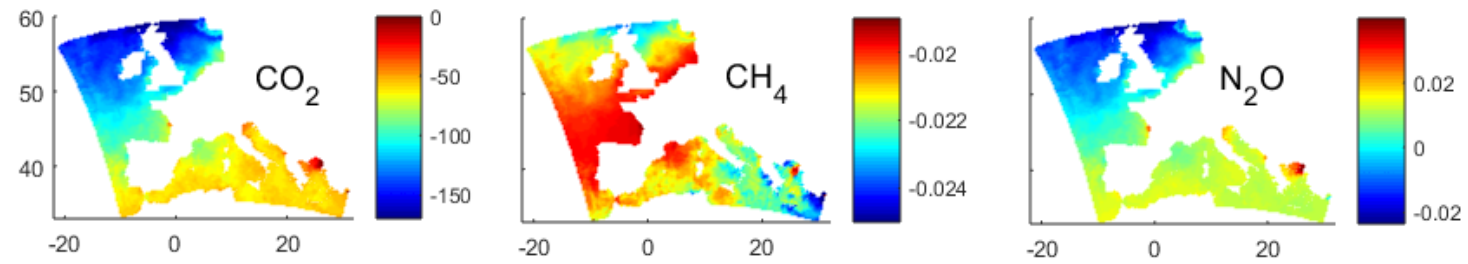

Figure 2: Bias in the gas mass balance for the European coastal ocean

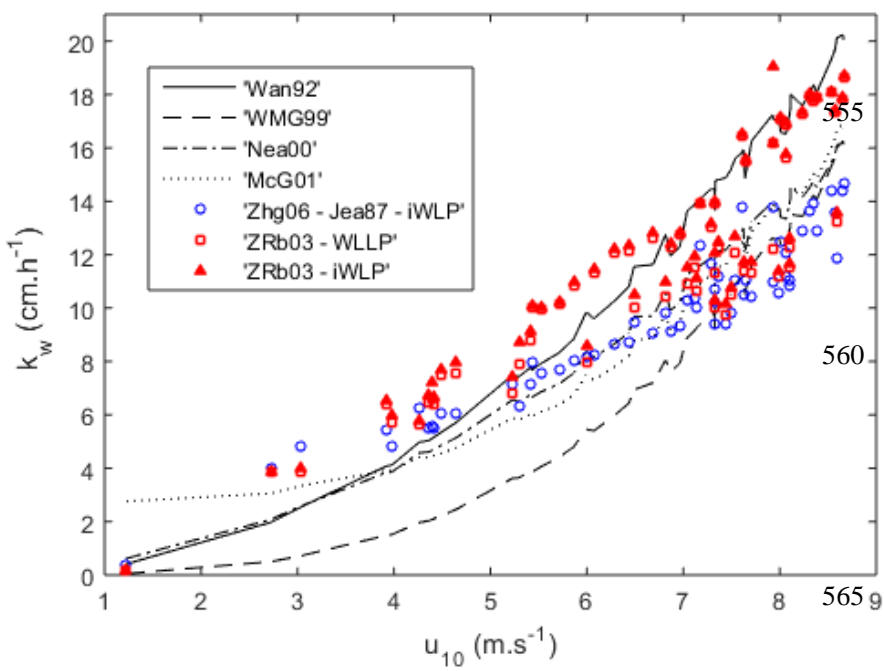

Figure 3: Comparing transfer velocity

algorithms using observed data 
Geosci. Model Dev. Discuss., doi:10.5194/gmd-2016-273, 2016 Manuscript under review for journal Geosci. Model Dev.

Published: 23 November 2016

(c) Author(s) 2016. CC-BY 3.0 License.

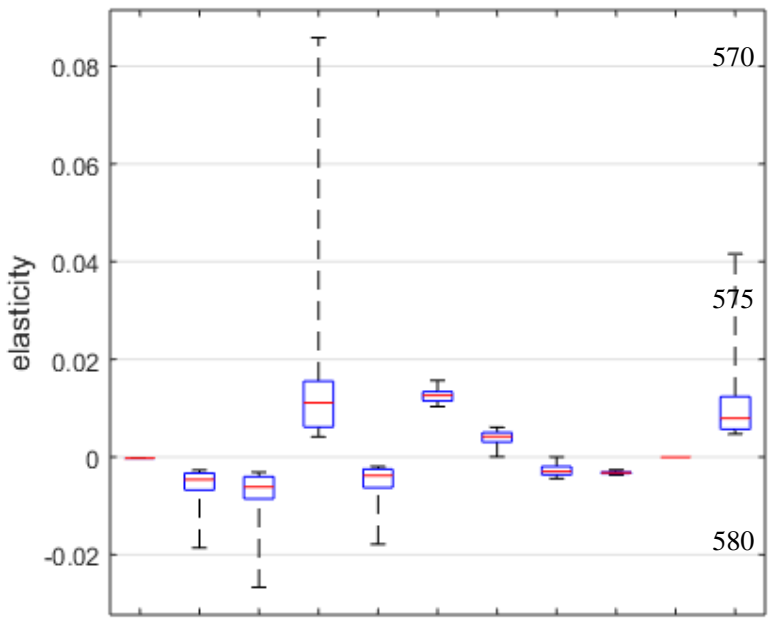

$T(0) T(h) P(0) P(h)$ hr u10 Hs Lp fp SSS SST
Figure 4: Elasticities of the transfer velocity to its forcing functions.
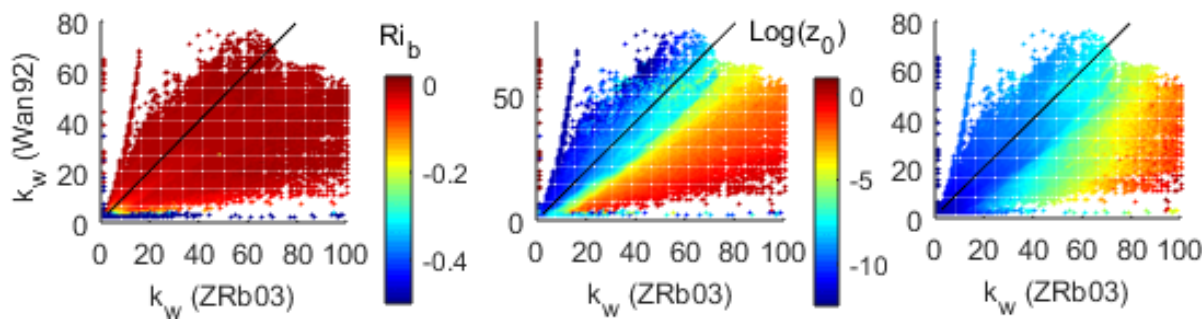

$u_{\star}$

Figure 5: Applying the modelled data about the European coastal ocean for a direct comparison between the $k_{w}$ estimates.
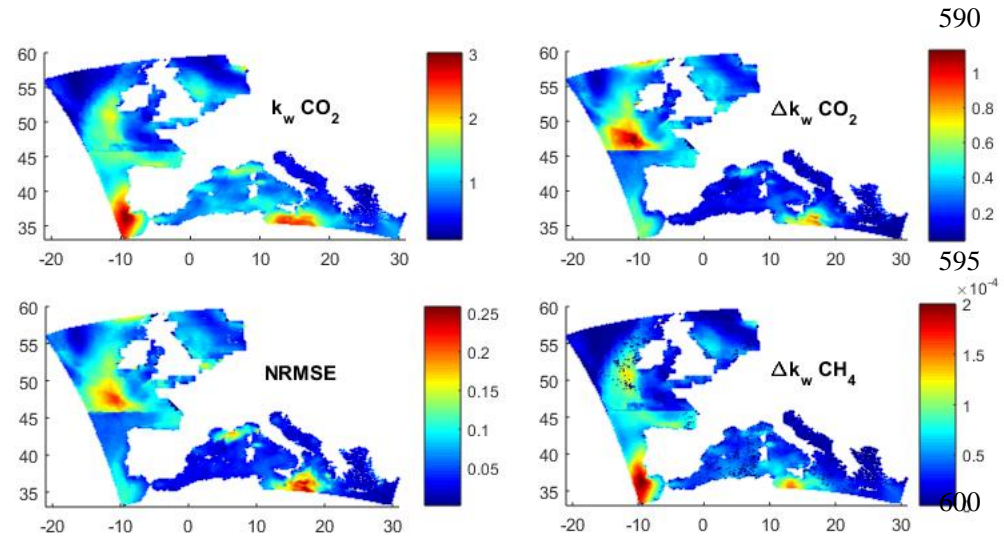

Figure 6: Comparing transfer velocity algorithms using modelled data 
Geosci. Model Dev. Discuss., doi:10.5194/gmd-2016-273, 2016

Manuscript under review for journal Geosci. Model Dev.

Published: 23 November 2016

(c) Author(s) 2016. CC-BY 3.0 License.

Figure 1: Comparing solubility formulations: $\left(\mathrm{k}_{\mathrm{H}}\right)$ Henry's constant estimated from (Joh10) Johnson, 2010, or

(Sar13) Sarmiento and Gruber, 2013. Colorscale: $\mathrm{k}_{\mathrm{H}^{`} \mathrm{~J} o h 10} / \mathrm{k}_{\mathrm{H}}$ 'Sar13'.

Figure 2: Bias in the gas mass balance for the European coastal ocean: comparing algorithm by Johnson (2010) to compilation by Sarmiento and Gruber (2013). Colorscale: $\Delta$ ton $\cdot \mathrm{m}^{-1} \cdot 121 \mathrm{~km}^{-2}$ i.e, bias in the gas mass estimated by each algorithm $\left(\Delta\right.$ ton) for the first meter depth $\left(\mathrm{m}^{-1}\right)$ in $11 \mathrm{~km}$ wide cells $\left(121 \mathrm{~km}^{-2}\right)$.

Figure 3: Comparing transfer velocity algorithms. The $\mathrm{k}_{\mathrm{w}}$ estimated by renowned $\mathrm{u}_{10}$-based formulations and by some of the most comprehensive alternatives provided in the FuGas 2.1, using the data observed at the Baltic. 'Wan92' - Wannninkhof (1992); 'WMG99' - Wanninkhof and McGillis (1999); 'Nea00' - Nigthingale et al. (2000); 'McG01' McGillis et al. (2001); 'Jea87' - Jähne et al (1987); 'Zhg06' - Zhang et al. (2006); 'ZRb03' - Zhao et al (2003); assembled using the 'WLLP' - wind log-linear profile or the 'iWLP' - iteratively estimated wind log-linear profile.

Figure 4: Elasticities of the transfer velocity to its forcing functions $\left(\partial \mathrm{k}_{\mathrm{w}} / \mathrm{k}_{\mathrm{w}}\right) /(\partial \mathrm{x} / \mathrm{x})$. The $\mathrm{k}_{\mathrm{w}}$ estimated by the iterative wind log-linear profile (iWLP) with the Zhao et al (2003) $\mathrm{k}_{\text {bubble }}$ term (ZRb03).

Figure 5: Applying the modelled data about the European coastal ocean for a direct comparison between the kw estimates by the ESM standard and our best performing comprehensive.

Figure 6: Comparing transfer velocity algorithms using modelled data: $\left(\mathrm{k}_{\mathrm{w}} \mathrm{CO}_{2}\right)$ estimated by the 'iWLP' iterative Wind Log-Linear Profile and the 'ZRb03' - Zhao et al. (2003) formulation, $\left(\Delta \mathrm{k}_{\mathrm{w}} \mathrm{CO}_{2}\right)$ difference between the iWLP with ZRb03 and the Wan92' - Wanninkhof (1992) formulation, (NRMSE) Normalize Root Mean Square Error between the iWLP with ZRb03 and the Wan92, , $\left(\Delta \mathrm{k}_{\mathrm{w}} \mathrm{CH}_{4}\right)$ difference between the single and double layer schemes using the iWLP with ZRb03. Colour scale: volume (or $\Delta$ volume) transferred in units of $\mathrm{Km}^{3} / 66 \mathrm{~h}$, except for NRMSE. 